\title{
RAISING THE QUALITY OF MUSLIM LEARNING: BROADENING THE CURRICULUM
}

\author{
Abdul Karim Abdullah*
}

\begin{abstract}
Two efforts have taken place in the Muslim world in recent decades - 1977 to 1996 - to reform education. The first initiative was launched by the OIC. A parallel attempt was launched by the IIIT. The latter was in certain aspects a response to the former. While the two efforts shared a common aim - the reform of Muslim education - they adopted different approaches to realise this objective. The differences between the two approaches are due to different perceptions about the reasons for the decline of Muslim education, and how it may be overcome. The OIC initiative traced the problems in Islamic education to a dualism which separated religious studies from contemporary subjects. This approach was content with integrating "contemporary" subjects in established Islamic studies. The Islamisation movement, by contrast, insisted that contemporary subjects needed to be "Islamised" before being introduced into the curricula of Islamic institutions of learning. In retrospect, the integration approach has proven enduring and resilient compared to the Islamisation approach. Currently, it is being implemented successfully in the Gulf region and in nations such as Malaysia.

Keywords: reform, integrated curriculum, Islamisation of knowledge, education.
\end{abstract}

\section{Introduction}

Two initiatives have been carried out in recent decades to address issues in Muslim education. The first was organised by the OIC. The second was launched, shortly after the first, by the IIIT. The two had comparable aims: the revitalisation of the Muslim world by means of educational reform. However, they recommended different approaches to achieve this aim.

Broadly speaking, the two perspectives reflect the "reformist" and "revivalist" perspectives on education, respectively. These perspectives advocate different approaches to reforming education because they understand the factors that contributed to the decline of Muslim education differently.

Participants in the OIC initiative saw the deterioration of Muslim education as resulting chiefly from a dualism in learning. This dualism, a legacy of colonialism, 
contributed to the marginalisation of present-day knowledge. Hence, the OIC initiative called for integrating the study of present-day subjects within the curricula of Muslim institutions of learning.

The Islamisation approach was part of a movement that sought to Islamise not only knowledge but the community as a whole as well as all its institutions. ${ }^{1}$ The IIIT initiative saw the chief threat to Muslims in globalisation. A number of commentators expressed concern that "un-Islamic" knowledge in particular might undermine the faith of the Muslims. Thus, they recommended Islamising all such knowledge before it was introduced into the curriculum.

By contrast, advocates of the "integrated curriculum" approach do not differentiate, as do the supporters of Islamisation, between knowledge that is Islamic and knowledge that is "un-Islamic." To them, knowledge is already Islamic. Thus, they have few reservations about the allegedly harmful effects of learning present-day knowledge.

Unlike the Islamisation approach, the supporters of an integrated curriculum do not see a fundamental incompatibility between present-day knowledge and Islam. They view Islam and science as complementary rather than as mutually exclusive. This approach is not without precedent, having already been apparent in the work of late nineteenth and early twentieth century reformers, such as Muhammad 'Abduh. However, with the rise of Islamic consciousness in the late 1970s, largely in response to a range of perceived threats to Muslim faith, Islamisation began to take center stage.

As the limitations of the Islamisation movement have begun to emerge, however, the "integrated curriculum" approach started to gain new popularity. Currently, the implementation of the "integrated curriculum" is gathering pace in different parts of the Muslim world, in particular in the Gulf region and in Malaysia. Islamisation, nonetheless, retains a significant following in nations such as Indonesia.

This paper recommends implementing the "integrated curriculum" model. ${ }^{2}$ If properly implemented, this approach achieves both of the chief aims of education: it helps to nurture and protect the students' spirituality while equipping them for the job market - at the same time.

\section{Need for Reform}

A number of commentators noted that Islamic institutions of learning do not prepare young people for the job market very well. ${ }^{3}$ Reflecting on the experience of the Islamic University College of Malaysia, established in 2000 (upgraded to a university in 2007) one observer noted that, while Islamic studies was gaining popularity among parents and students, "the majority of graduates" had difficulties in finding "suitable employment." 
Youths remain unemployed in other parts of the Muslim world. This has played a part in the radicalisation of some young people. In Tunisia, for example "[a] third of recent college graduates can't find work. Frustration led young people to take to the streets in 2011; a similar desperate impulse is now driving other young people toward jihad."

One effective way to address the problem of unemployment is to teach students knowledge required in the labour market. Young people need skills in computer science, engineering, medicine, and additional areas. Broadening the programs in Muslim institutions of learning will require a "substantial change in the curricula of all educational institutions and, in particular those of the madrasahs."

In the past, "worldly" subjects were taught apart from the "traditional" Islamic subjects. This resulted in a dualism of the education system. ${ }^{7}$ In order to overcome this dualism, the study of present-day subjects needs to be integrated with the study of Islamic subjects. A holistic, integrated approach is needed. This also requires "adding sufficient number of courses in humanities to the science and engineering curricula, by cross-disciplinary interaction and collaboration." 8

Accordingly, it is necessary to broaden the curriculum of Muslim educational institutions, and incorporate disciplines that will enable graduates to become better qualified for the job market. This does not mean that Islamic studies have to be marginalised; contemporary disciplines should, however, be taught together with Islam. Integrating contemporary disciplines in the curriculum will help restore balance in education, a balance that was initially skewed by the separation of the study of Islam from the study of contemporary subjects.

An overview of reform initiatives in recent decades shows that there is some distance to go in achieving integration. There are a number of factors that explain why the implementation of an integrated curriculum has been rather sluggish. Perhaps the chief among these was the Islamisation of knowledge movement.

\section{Islamisation of Knowledge}

Islamisation as a movement sought to re-assert Muslim dignity in the face of various present-day challenges. Islamisation was not confined to knowledge, but extended to all aspects of life. " "Islamisation is a global programme which has been generally accepted by the Muslims to check further erosion of their worldview, culture and achievements by the so-called Western system of education." 10

Muslims became alarmed that exposure to "imported" knowledge might weaken their faith. The primary threat was perceived to be the attempts to incorporate what was perceived as "un-Islamic" knowledge into the curricula of Muslim institutions of learning. 
It was hoped that Islamisation of knowledge would become "a tool for sanitising the so-called secular disciplines." "Islamisation resulted in the establishment of a number of Islamic universities and Institutes in nations such as Malaysia. It also included initiatives to implement penal law in a number of Muslim nations, in particular in the 1980s.

For a time, Islamisation of knowledge held sway. In practice, however, Islamisation rarely extended beyond quoting a few verses from the Qur'an, in a process known as "spraying." In addition, it was becoming clear that the effort to "Islamise" knowledge was exposed to deeper problems.

First, to speak of Islamising knowledge presupposes that there is knowledge that is not Islamic. It is this knowledge, presumably, that requires Islamisation. However, from the perspective of the Qur'an, to categorise knowledge into Islamic and un-Islamic is problematic. For the Qur'an does not differentiate between knowledge ( ' $\mathrm{ilm}$ ) that is Islamic and that which is not Islamic. Rather, it differentiates between knowledge and ignorance. The very purpose of revelation is to enable man overcome ignorance by attaining knowledge. In other words, the categorisation of knowledge into "Islamic" and "un-Islamic," presupposed by the attempt to Islamise knowledge, appears to be alien to the epistemology of the Qur'an.

Moreover, the expression "Islamisation of knowledge" suggests the idea that knowledge is monolithic. That there are different types of knowledge, however, is reflected in the fact that different kinds of knowledge are arrived at in different ways. Attaining different types of knowledge requires different methods. A methodology suitable for discovering knowledge in physics may not be suitable for acquiring knowledge in the field of metaphysics. Likewise, the methodology of theology differs from the methodology of the empirical sciences.

This does not mean, however, that different kinds of knowledge are mutually exclusive, or entirely apart from each other; rather, different kinds of knowledge complement each other. For example, while theology speaks of ethics and values, empirical disciplines explore the relationships between variables in the physical world. They seek to describe the Is rather than prescribe the Ought. Thus, empirical knowledge in itself is morally neutral. It is how empirical knowledge is used that lends itself to Islamisation, rather than the knowledge itself.

It is important to realise that engagement in scientific inquiry does not require a person to subscribe to assumptions that contradict the teaching of Islam. Results of experiments are not affected by the faith - or lack of it - of the persons conducting them. ${ }^{12}$

The laws that govern the relationships between different parts of the physical universe have been established by God. They constitute a part of what is known as the sunnah of God. The study of the relationships between different parts of the physical universe has been referred to as the study of the "second book" of 
God, the "book of nature." Reflection on the signs of God can bring the scientist closer to his Creator, and in that way increase the scientist's God-consciousness (taqwa).

Worldly knowledge is gained with the help of the empirical sciences. Man acquires knowledge of physical phenomena by means of observation, measurement, and analysis. Man's ability to attain metaphysical knowledge, however, is limited. ${ }^{13}$ That is why knowledge beyond the scope of empirical enquiry was revealed. The challenge is to integrate these two types of knowledge in a way that enables a person to lead a meaningful and fulfilling life.

Given the difficulties above, a number of scholars suggested alternative expressions to identify precisely what needs, or indeed can be, "Islamised."14 Some suggested Islamising "the human sciences."15 Others favoured the Islamisation of "contemporary knowledge." ${ }^{\text {"16 }}$ Still others suggested Islamising "education." 17

\section{Conferences: 1977 to 1996}

Two series of conferences on education were held, more or less concurrently, in recent decades in different parts of the Muslim world. The first was organised by the OIC and consisted of six conferences. The second was organised by the Association of Muslim Social Scientists (AMSS) and the International Institute of Islamic Thought (IIIT). This series consisted of four conferences. The first series took place between 1977 and 1996. The second series took place between 1977 and 1987.

Despite significant commonalities, each series of conferences had a distinct focus. The focus of the first series was on improving education. The focus of the second series, however, was on Islamisation, in particular the Islamisation of knowledge. ${ }^{18}$

It appears that over the next few years the latter conferences impacted the former more that the former impacted the latter. This is evident from the fact that the last conference of the first set was dedicated almost entirely to the Islamisation of knowledge. ${ }^{19}$ The emphasis on the Islamisation, however, was short-lived. It began to wane towards the end of the millennium. We look at the OIC-sponsored events first.

The First World Conference on Islamic Education took place in 1977, in Saudi Arabia. Its theme was "The Basis for an Islamic Education System." It suggested a holistic education capable of enabling each individual to realise his or her potential. The conference proposed broadening the curriculum, a process that would be facilitated by a classification of knowledge into revealed and acquired. ${ }^{20}$ 
Participants at this First World Conference recommended integrating the study of literature, literary criticism, arts and social science within the existing curricula of Islamic schools and universities. The conference also recommended that, "The causes of the development of sciences during the heydays of Islam and their subsequent decline should be carefully investigated." ${ }^{21}$ The main focus of the conference was on improving the quality of Islamic education.

The First World Conference laid the groundwork for establishing the World Centre for Organisation of Islamic Education in Makkah in 1981, under the OIC. The purpose of the Centre was to provide leadership in educational reform. A few years later, however, the Centre was merged with the Umm ul-Qura campus. As a result, the international character of the Centre was reduced. ${ }^{22}$

The Second World Conference on Muslim Education took place in 1980, in Pakistan. "The main task of the conference was to design curricula for different ladders of education with the view of bridging the gap between secular and madrasah systems of education." ${ }^{23}$

This conference focused on the design and implementation of "integrated Islamic curricula at all levels and in all subjects (emphasis added). ${ }^{24}$ The conference recommended allocating twenty per cent of classroom time to religious studies. The rest of the time would be allocated to the study of nonreligious subjects.

The Third World Conference on Muslim Education was held in 1981, in Bangladesh. Its main purpose was to provide guidance in the "preparation of textbooks for use in Muslim and non-Muslim schools." ${ }^{25}$

The Fourth World Conference on Islamic Education took place a year later, in 1982, in Indonesia. The main focus was on "Islamic Methods of Teaching." It recommended that teaching be value-centred; instead if applying a dogmatic approach, the learning process should be interactive and impart ethical values.

Commenting on the recommendations of the first four conferences, Syed Ali Ashraf noted that, "No one has tried to implement them." 27 The reason was twofold. First, there was confusion between the Islamic and the western components of education. Second, there was confusion over methodology, classification of knowledge, and the curricula to be adopted. Third, there was a shortage of textbooks.

The Fifth World Conference on Islamic Education took place in Egypt, in 1987, "to review the achievements of previous conferences and examine ways and means of implementing of their resolutions." ${ }^{.28}$

The Sixth World Conference on Islamic Education took place in South Africa, in 1996. This Conference appears to have adopted the "Islamisation of knowledge" approach advocated by the IIIT conferences, the last of which took place nine years earlier (1987) in Sudan. 
The purpose of the Sixth Conference was "to prepare lesson plans and subject teaching guidelines for teaching of various school subjects from the Islamic point of view." ${ }^{29}$ Most of the conference took the form of workshops.

We now turn to the IIIT sponsored events. As mentioned previously, the focus of the IIIT conferences was the Islamisation of knowledge. This focus appears to have been triggered by fears that incorporating present-day knowledge in Islamic institutions of learning, without "Islamising" it first, would undermine the faith of Muslims.

The First World Conference on the Islamisation of Knowledge was organised by the forerunner of the IIIT, the Association of Muslim Social Scientists. ${ }^{30}$ It took place in Switzerland in the same year (1977), a few months after the first OIC event.

The conference resulted in the setting up of IIIT in 1981, with headquarters in Herndon, VA, USA. ${ }^{31}$ IIIT organised the remaining three conferences on the Islamisation of knowledge. ${ }^{32}$

The Second World Conference on the Islamisation of Knowledge, was coorganised by IIIT and the International Islamic University of Islamabad, and took place in 1982, in Pakistan. The conference was inaugurated by the then president of Pakistan, General Zia al-Haq.

The conference focused on the Islamisation of "individual disciplines." 33 Isma'il al-Faruqi presented a paper with the title, "Islamization of knowledge: Problems, Principles and Prospects."

The Third World Conference on the Islamisation of Knowledge took place in Malaysia, in $1984 .{ }^{34}$ Its purpose was to show how individual disciplines could be Islamised. ${ }^{35}$ The conference constituted part of a wider Islamisation agenda then underway in Malaysia, itself part of a resurgence in Islamic consciousness. ${ }^{36}$

Expressing his frustration at what appeared to be a lack of co-operation between Muslim institutions of higher learning and IIIT, al-Faruqi stated after the Third Conference that, with the exception of the Islamic University of Islamabad:

[N]ot one educational institution in the Muslim world had moved a finger to Islamize knowledge, to produce Islamic textbooks for college use in the disciplines, or the tools of research necessary for the writing of these textbooks ... On the official level where the power to decide rests, one finds little more than lip-service, either made by the ignorant or designed otherwise to mislead the masses. ${ }^{37}$

The Fourth World Conference on the Islamisation of Knowledge took place in 1987, at the University of Khartoum, Sudan. The conference was organised by IIIT and the University of Khartoum. Its theme was "Methodology of Research, Behavioral Sciences and Education." ${ }^{38}$ 
In retrospect, it appears that the "Islamisation of knowledge" agenda fell short in a key area: because little present-day knowledge was successfully "Islamised," few present-day sciences were included in the curricula of Islamic institutions of learning. The result was what came to be known as a "science deficit."

\section{The Science Deficit}

Despite a plethora of initiatives to reform education, the "science deficit" in Muslim education is largely why the limited employability of Muslim graduates remains a reality. Various commentators have accordingly urged the Muslim community to broaden the curriculum to incorporate the study of present-day sciences.

The October 2003 Arab Human Development Report (AHDR) on 'Building a Knowledge Society' focused on developing such scientific knowledge. It stated that Muslims could no longer blame their problems on the West and colonialism. Rather, "the report blame[d] authoritarian thought, lack of autonomy in universities, the sorry state of libraries and laboratories, and under-funding in the Arab world." ${ }^{39}$ The report called for the revival of ijtihad, for "reuniting reason with revelation." ${ }^{\prime 40}$

A report by the Organisation of the Islamic Conference (OIC) in 2004 on the status of science in Muslim countries noted the persistence of a "science deficit" in all 57 Muslim nations. The results of a study on scientific research carried out between 1995 and 2004 are summed up below:

\begin{tabular}{|l|l|l|l|}
\hline Turkey & \multicolumn{1}{|c|}{$\begin{array}{c}\text { Number of } \\
\text { publications } \\
\mathbf{( 1 9 9 5 - \mathbf { 2 0 0 4 } )}\end{array}$} & $\begin{array}{c}\text { Publications per } \\
\text { million population } \\
\text { (rank) }\end{array}$ & \multicolumn{1}{|c|}{$\begin{array}{c}\text { Publications } \\
\text { growth rate** }\end{array}$} \\
\hline Egypt & 82,407 & $116.5(4)$ & $82.30 \%$ \\
\hline Iran & 27,723 & $38.9(8)$ & $13 \%$ \\
\hline Saudi Arabia & 19,114 & $28.0(10)$ & $123 \%$ \\
\hline Malaysia & 17,472 & $72.62(6)$ & $-5.85 \%$ \\
\hline Morocco & 10,674 & $43.75(7)$ & $31.70 \%$ \\
\hline Nigeria & 10,113 & $33.1(9)$ & $9.70 \%$ \\
\hline Pakistan & 9,105 & $7.5(12)$ & $-8.40 \%$ \\
\hline Jordan & 7,832 & $5.3(13)$ & $24.50 \%$ \\
\hline Kuwait & 6,384 & $119.33(3)$ & $24.30 \%$ \\
\hline Lebanon & 5,930 & $254.5(1)$ & $-0.50 \%$ \\
\hline Indonesia & 5,118 & $152.6(2)$ & $12.45 \%$ \\
\hline
\end{tabular}




\begin{tabular}{|l|l|l|l|}
\hline Bangladesh & 4,745 & $3.5(14)$ & $15.50 \%$ \\
\hline $\begin{array}{l}\text { United Arab } \\
\text { Emirates }\end{array}$ & 4,389 & $108.64(5)$ & $30.00 \%$ \\
\hline Uzbekistan & 3,924 & $15.1(11)$ & $-11.00 \%$ \\
\hline
\end{tabular}

**Percentage change in publication rate over 2002-2004 compared with the 1998-2004 average

OIC member states publishing the highest number of science and technology papers from 1995-2004 ${ }^{41}$

These figures indicate several weaknesses. Firstly, although Muslim nations comprise 20 per cent of the world population, they contribute only 2.5 per cent of more than 11.5 million research papers published globally every year. The survey also makes it clear that the largest Muslim nations by population -i.e. Indonesia, Pakistan and Bangladesh - are far from being the most productive in science and technology. In terms of publications per one million of population, smaller nations such as Kuwait do much better.

It appears that better funding is required. The Muslim world must also "promote academic freedom and set up well-designed research funding programmes, quality educational and research institutes, and offer incentives for undertaking and publishing research." ${ }^{42}$

The Third Extraordinary Session of the Islamic Summit Conference, held in Makkah in December 2005, proposed a strategic ten-year action plan to promote modernisation, science and technology throughout the Muslim world. In addition, it condemned all forms of extremism and violence. ${ }^{43}$

The implementation of the 2005 Makkah Declaration was discussed two years later, at a Forum in Malaysia, held on 1-3 September in 2007. Abdullah Ahmad Badawi, the then prime minister of Malaysia and Chairman of the OIC, observed that since the adoption of the Declaration, "we have not been able to move significantly beyond the preparatory, planning and coordination stages." ${ }^{\prime 4}$

In order to implement the ten-year plan successfully, Badawi emphasised the need to strengthen collective resolve, develop human resources, provide more generous funding, and establish partnerships with world players.

At a meeting of the Task Force on Science at Universities in the Muslim World, assembled in Malaysia in 2014, its Chairman reported that OIC nations still lag behind other nations of the world in science and technology. "According to UNESCO," he observed, "the average spending for science in OIC countries is only one per cent of the national budget ... the current pedagogy needs to be urgently evaluated and changed." "[C]ritical thinking or inquiry-based learning is also not facilitated in most parts of the Muslim world" he added. ${ }^{45}$ 


\section{Intellectual Challenge}

During the colonial era, Islamic schools focused on religious studies while institutions administered by resident authorities taught present-day subjects. As a result, a dualism developed. In some schools - in particular, the madrassahs - this dualism persists to this day. Because of it, Islamic religious institutions "fail to train students to enter a workforce with skills necessary to become active participants in society." ${ }^{46}$ Accordingly, "For madrassahs, the principal challenge is how to transmit religious knowledge yet remain relevant and adaptive to ongoing changes." ${ }^{47}$

Natural science disciplines are scarce in many Muslim institutions of learning. A major reason for this is the perception, widespread in parts of the Muslim world, that human sciences are worldly, and therefore to be avoided by Muslims, who should concentrate on the hereafter.

While a focus on the hereafter is laudable, it needs to be remembered that the Qur'an does not ask us to focus exclusively on the hereafter. Helping the orphans, performing good deeds, and serving God in other ways all take place in this world.

As previously noted, the Qur'an explicitly encourages the exploration of the physical universe, the "second book of God," in particular the countless signs (ayat) of God that may be found within it. The Qur'an brings our attention to the wonders of the world as a way of raising awareness of the world to come:

Approximately 750 verses, or nearly one-eighth of the Qur'an, exhort the readers to study nature, history, the Qur'an itself, and humanity at large. The text employs a range of expressions in its appeal to those who listen (yasma'un), those who think (yatafakkarun), those who reflect (yatadabbarun), those who observe (yanzurun), those who exercise their intellect (ya'qilun), those who take heed and remember (yatadhakkarun), those who ask questions (yas'alun), those who develop an insight (yatafaqqahun), and those who know (ya'lamun). ${ }^{48}$

Commitment to faith does not require the rejection of empirical knowledge. Max Planck noted that, "with religious people, God appears at the beginning of their thinking, with natural scientists, at the end." ${ }^{49}$ It must be remembered that God created not only humanity, but also the world; thus to study the world of nature is to study an Islamic subject.

Moreover, not everyone can become a religious teacher or imam. The world of today also requires engineers, doctors, and lawyers. Thus, it is less than reasonable to expect everyone to specialise in religious studies. ${ }^{50}$ 
Islam and experimental science are not mutually exclusive. ${ }^{51}$ Each offers knowledge, albeit of a different kind. Revelation provides guidance, while knowledge of science enhances our ability to cultivate the earth. One observer put it this way:

[T] here is no contradiction between secular and religious knowledge ... the division between the two is false and artificial ... I do not suspend my rational capacity on reading the Koran or listening to a sermon, and I do not shelve my religious convictions when I conduct scientific experiments or operate on my patients. ${ }^{52}$

The decline of learning in the Muslim world has been attributed to a number of factors. These include the sacking of Baghdad, the expulsion of the Muslims from Spain, the effects of the crusades, the disintegration of the Ottoman caliphate and the effects of European colonisation: ${ }^{33}$

The creative impulse of Islamic thought suffered setbacks as a result. Muslims were also beset with many internal problems including the alienation of philosophers, scientists, and thinkers from the theologians, sectarian controversies, and the prevalence of intellectual conservatism and taqlid (imitation of past authority). Philosophy and the sciences fell into a rapid decline while more rigid forms of instruction and narrower curricula prevailed. It was argued that orthodoxy was being threatened and that there was a need to restrain thinkers in order to defend religion. The latitude and diversity of discourse that expanded the scope of religious sciences, kalam, tafsir, hadith, and fiqh gave way to narrower criteria of kufr, bid'ah, and taqlid and the so-called closing of the door of ijtihad (sadd bab al-ijtihad). ${ }^{54}$

While not a few contemporary Muslims appear to experience a phobia of scientific disciplines (especially mathematics), the natural sciences thrived during the golden age of Islam. More than 800 verses in the Qur'an invite readers to contemplate the "signs of God." They ask the reader to use his reason ('aql). According to one observer:

$\mathrm{Ilm}$, the urge to know, and ijtihad ... were central to classical Islam and produced a culture with science and rationality at its core ... [however,] as ijtihad became increasingly irrelevant... ilm was increasingly reduced to religious knowledge... only the pursuit of religious knowledge came to be seen as important ... 55

The view that a person must be either a believer or a thinker is hardly in keeping with the message of the Qur'an. Certainly, thinking rarely takes place in 
isolation from believing. Conversely, a person is unlikely to attain to true faith without thinking. ${ }^{56}$ Faith without thought is little different from fanaticism. The use of the mind is a necessary, even if not a sufficient condition for attaining faith.

[T] he majority of Muslims today are ... woefully uninformed of the depth and scope of their rich heritage on the authoritative validity of reason. Thinking Muslims should work to vindicate the symbiotic relation of faith and reason in their religion and see it as a source of enrichment and contribution of Islam to human understanding and civilization. ${ }^{57}$

Awareness of truth is reached by intellection and intuition. Knowledge of the material physical world is perceived rationally, by means of the empirical method. Spiritual awareness, by comparison, is achieved intuitively or - as the Qur'an puts it - by the "heart."

This does not mean, however, that intuition plays no role in science. Not a few of the greatest scientific discoveries were arrived at intuitively. Similarly, both the intellect and sensory perception are required for the contemplation of the signs (ayat) of God, in the physical world as well as in the domain of spirituality. The intellect is also indispensable in understanding the Qur'an.

The inability to integrate reason and revelation may result in a crisis in human thought. Resolving this crisis requires the integration of religious and worldly sciences:

The process of bringing the religious and the secular elements together is, from the Islamic point of view, a restoration of the link between reason and revelation, or between the role of the mind in appreciating (comprehending and interpreting) revelation and guiding the mind by means of the revelation's objectives, its comprehensive and universal outlook, and its living and civilizational values. Thus, the joining of the two wings in the pursuit of reform is an intellectual process in its methodology and style. ${ }^{58}$

Intuition and intellect work together in the quest for knowledge and wisdom, whether in the world of nature or in the realm of spirituality. The alleged incompatibility of reason and revelation is alien to the Qur'an. In fact, the Qur'an frequently exhorts man to "use his reason."

In numerous places and a variety of contexts, the Qur'an calls on its readers to think, reflect and reason on the basis of what they experience and observe. They are encouraged to travel and explore the tracts of the earth, to study and observe the movement of the planets, the sun, and the moon, and reflect on the signs they see around them. ${ }^{59}$ 
Knowledge gained within the empirical disciplines may be used for good or evil. Revelation teaches man the difference between the two, and how to use worldly science in ways that are in harmony rather than at odds with the teaching of Islam.

Scientific knowledge may contribute to human welfare, "but it is ethically neutral and fails to guide us in the realm of the objectives of life, its values and norms and the nature of ultimate reality..." ${ }^{\prime 60}$ Thus, the use of empirical knowledge has to be in harmony with ethical principles, grounded in revelation. Ultimately, it is the user of empirical knowledge that needs to be Islamised, not his knowledge. After all, Islam was revealed for the benefit of humankind, not for abstract formulas or "laws of nature."

\section{Integrated curriculum}

As it became clear that the implementation of the Islamisation of knowledge agenda would fall short of expectations, reformers began to look elsewhere. Increasingly, they turned to the "integrated curriculum" model.

As an approach, the "integrated curriculum" model distinguishes itself by its pragmatic nature. It does not see an inherent conflict between present-day knowledge and Islam; it holds that the knowledge people need today may be acquired without adversely affecting a person's spirituality. An “integrated curriculum" combines the study of present-day disciplines with traditional Islamic learning. Traditional learning provides students with ethical guidelines, while the study of contemporary subjects equip them with marketable skills. In this way, students retain their Islamic identity and become equipped for the job market at the same time.

The "integrated curriculum" approach started to become popular during the 1990s. It has been endorsed by The First Dubai International Conference in Higher Education, 2013 as well as The Second Dubai Conference on Education, 2014. Both conferences emphasised quality. One result was the establishment of partnerships between Muslim and foreign universities, in which the latter set up branch campuses in partnership with the former. ${ }^{61}$ These agreements have seen foreign professors, instructors, and lecturers brought into Muslim nations. Muslim students are also sent abroad; upon their return, the knowledge and skills that they learned abroad are then applied in local settings. Returning graduates are regularly appointed to key positions in different sectors. A change from Arabic to English as the language of instruction (except in Islamic studies) has also taken place as a result of such partnerships. These efforts should be expanded and applied in other parts of the Muslim world.

Apart from the Gulf nations, Malaysia has made significant strides in 
implementing the integrated curriculum model. This is evident from the setting up of branch campuses for such foreign universities as Monash University, Nottingham University, Curtin University, Cardiff University and the University of Newcastle. The presence of these institutions has transformed Malaysia into an international education hub, capable of attracting large numbers of foreign students to its shores to pursue higher education in various areas of specialisation. ${ }^{62}$

\section{Conclusions and Recommendations}

The two reform initiatives surveyed above appear to have been guided by different visions, each with its origin in a different context. The IIIT narrative emerged from the struggle for liberation in Egypt. Perhaps in response to the intensity of this struggle, the supporters of "Islamisation" became inclined to make few concessions to what appeared to them as "secular" and "western" influence.

The advocates of integration, by comparison, take a less sinister view of the dangers - imagined or real - of present-day knowledge. They do not experience the "cultural schizophrenia" felt by the advocates of Islamisation. The supporters of the "integrated curriculum" do not view present-day knowledge as fundamentally "western" and thus contrary to Islam. Indeed, they frequently highlight the contributions of Muslim scholars to the sciences. ${ }^{63}$

The OIC-sponsored conferences were broadly supportive of the integrated curriculum approach; knowledge discovered by both Muslim and non-Muslim civilisations can bring benefits to all. In other words, there was no need to "reinvent the wheel," just to ensure that the wheel would be "Islamic."

The advocates of Islamisation, by contrast, are less sanguine about integrating present-day knowledge in Muslim centres of learning. The effort to "Islamise" knowledge, regardless of its type, however, had a number of unwelcome consequences.

By prioritising the Islamisation of knowledge rather than its acquisition, Islamisation altered, however temporarily, the scope and direction of reform. By diverting efforts from the broadening of the curriculum to its Islamisation, the advocates of Islamisation transformed what was essentially an educational effort into a missionary struggle. The OIC and the IIIT initiative reflected what may be termed as an intellectual and activist approach to reforming education, respectively.

Another unwelcome consequence of Islamisation was that it appears to have hindered Muslims from adding to knowledge. For contributing to knowledge presupposes mastering present-day knowledge first. Yet the mastery of existing knowledge proved elusive, as it could not begin until it was suitably "Islamised." In this way, the well-meaning although ill-conceived effort to "Islamise" knowledge 
in fact impaired efforts of Muslim scholars to add to existing knowledge. In this way, the Islamisation of knowledge delayed the realisation of the very aim its supporters were seeking to achieve: the re-invigoration of the Islamic civilisation.

Given the problems produced by Islamisation, it is accordingly recommended that the integrated curriculum model of reforming education be prioritised in preference to the Islamisation of knowledge. The integrated approach combines the best of present-day learning with Islamic heritage. It should be maintained, strengthened and expanded. The fallacy of seeing religious knowledge as "incompatible" with worldly knowledge needs to be abandoned. There is a need for balance between empirical and religious knowledge.

In order to compete in the contemporary world, mastery of present-day subjects, in particular present-day disciplines, is a sine qua non. Muslim students need a good foundation in Islamic studies; however, they also need to learn skills that will enable them to participate in the economy. These skills can be acquired by learning contemporary subjects such as information technology, engineering, architecture, and related disciplines. In this way, graduates may become good Muslims and qualified professionals at the same time.

- Islamisation of present-day disciplines, with the exception of the arts, humanities and social sciences (for example economics), should be discontinued.

- Efforts should instead be focused on producing an integrated curriculum that can be widely implemented in Muslim educational institutions.

- Disciplines such as physics, biology, biotechnology, engineering, architecture and medicine need to be incorporated in the curriculum.

- Each of these subjects should have a faculty of its own, with a significant degree of autonomy.

- The primary language of instruction, except in Islamic studies, should be English.

- Comparative and interdisciplinary studies should be encouraged.

- Muslims need to raise education budgets to match (or exceed) global levels.

- Better classrooms, laboratories and libraries need to be provided.

- Scholarships for needy, yet promising, students also need to be provided. 


\section{Notes}

* Abdul Karim Abdullah (Leslie Terebessy), Assistant Fellow at IAIS, earned his MA in political philosophy from the University of Toronto, Canada (1999) and a MEd (1986) from the University of Toronto's Ontario Institute for Studies in Education (OISE). A former lecturer, editor, writer and coordinator of the English programme at University Sains Islam Malaysia (USIM), his current projects involve research into the current financial crisis, critical thinking in Muslim societies, and Islamic Finance. He has edited Islamic Studies at World Institutions of Higher Learning (Kuala Lumpur: USIM 2004). He can be contacted at abdulkarim@iais.org.my.

1. For the nexus between "Islamisation" and the politics of identity, with special reference to the Egyptian colonial and post-colonial experience, see Mehmet Ozan Asik and Aykan Erdemir "Westernization as Cultural Trauma: Egyptian Radical Islamist Discourse on Religious Education," Journal for the Study of Religions and Ideologies, Vol. 9, No. 25 (Spring 2010) pp. 111-132, accessed online on 26 July 2016; <jsri.ro/ojs/index.php/jsri/article/download/251/250>

2. The "integrated approach" has been advocated by, amongst others, Nik Mustapha $\mathrm{Hj}$. Nik Hassan, at the International Conference on Islamic Studies in World Institutions of Higher Learning, organised by the Islamic University College of Malaysia, KUIM, on 29 - 30 July 2002, in Kuala Lumpur. See "Islamic Studies in the Era of Globalisation," in Islamic Studies in World Institutions of Higher Learning, Abd. Samat Musa, Hazleena Baharun, and Abd. Karim Abdullah (Eds.), Islamic University College of Malaysia, 2004, pp. 69-79.

3. Selvaraj Grapragasem, Anbalagan Krishnan, and Azlin Norhaini Mansor "Current Trends in Malaysian Higher Education and the Effect on Education Policy and Practice: An Overview," International Journal of Higher Education, Vol. 3, No. 1; 2014, pp. 85-93, p. 89, accessed online on 14 July 2016; <http:// files.eric.ed.gov/fulltext/EJ1067468.pdf>

4. M. B. Muda "Islamic Studies in Institutions of Higher Learning in Malaysia: Challenges and Prospects," Islamic Studies in World Institutions of Higher Learning, Abd. Samat Musa, Hazleena Baharun, and Abd. Karim Abdullah (Eds.), Islamic University College of Malaysia, 2004, pp. 39-60, p. 39.

5. George Packer "Exporting Jihad," The New Yorker, March 28, 2016, accessed online on 11 July 2016; <http://www.newyorker.com/magazine/2016/03/28/ tunisia-and-the-fall-after-the-arab-spring $>$

6. M. Umer Chapra, Muslim Civilisation: The Causes of Decline and the Need for Reform, quoted in mohammedamin.com, 4 June 2011, accessed online on 30 May 2016, <http://www.mohammedamin.com/Reviews/Muslim-civilisationthe-causes-of-decline-and-the-need-for-reform.html>

7. Mohammad Hashim Kamali "Classical and contemporary approaches to education: an Islamic perspective," Islam and Civilisational Renewal, Vol. 2, No. 3, April 2011, International Institute for Advanced Islamic Studies, pp. 447467, p. 459.

8. Mehdi Golshani, "From Knowledge to Wisdom: A Qur'anic Perspective," Islamic Studies, 44 (2005), p. 13, Quoted in Mohammad Hashim Kamali "Reading the 
signs: the Qur'anic perspective on thinking," Islam and Science, Volume 4, Number 2, Winter 2006, Center for Islam and Science, pp. 141-164, p. 163.

9. Yarrow Ruqiyya Nu'man, “Assuring quality outcomes: Benchmarks for higher education in Islamic countries," pp. 222-239, The $2^{\text {nd }}$ Dubai International Conference in Higher Education: Sustaining Success through Innovation, held on January 19-20, 2014, edited by Lulett Escarpe-Ibarra, Michigan State University Dubai, United Arab Emirates, BrownWalker Press, p. 225.

10. Rafiu Ibrahim Adebayo "Islamization of knowledge: its inevitability and problems of practicability in Nigeria," Muslim Education Quarterly, The Islamic Academy, Vol. 21, No. 1 \& 2, 2004, pp. 4-17, p. 5, accessed online on 8 June 2016; <http://unilorin.edu.ng/publications/adebayori/Adebayo,\%20R.I.\%20 Islamization $\% 20$ of $\% 20$ Knowledge.pdf $>$

11. Loc. Cit.

12. The faith of the scientist is, however, likely to influence the kind of experiments he may be interested in conducting.

13. Sobhi Rayan, "Education towards values," Islam and Civilisational Renewal, Vol. 2, No. 3, April 2011, Pluto Journals, pp. 468-481, p. 475.

14. Ghulam Nabi Saqeb "Islamization of Education," Conference Report on The Sixth International Conference on Islamic Education, held on 20-25 September 1996 in Cape Town in South Africa, The American Journal of Islamic Social Sciences, Vol. 14, No. 4, 1997, p. 115; accessed online on 11 June 2016; $<$ http://i-epistemology.net/v1/attachments/499_V14N4\%20Winter\%2097-\%20 Islamization $\% 20$ of $\% 20$ Education.pdf $>$

15. Mohd Kamal Hassan "The Integration of Human Sciences and Revealed Knowledge in the KIRKHS," IIUM at 25: The Path Travelled and The Way Forward, Syed Arabi Idid, (Ed.), IIUM Press, 2009, pp. 111-124, p. 111, accessed online on 1 Aug. 2016; < http://irep.iium.edu.my/1252/1/The_Integration_of Human_Science_and_Revealed_Knowledge_in_KIRKHS.pdf $>$

16. Rosnani Hashim \& Imron Rossid "Islamization of Knowledge: A Comparative Analysis of the Conceptions of AI-Attas and AI-Faruqi," Intellectual Discourse, 2000, Vol. 8, No. 1, pp. 19 - 44, pp. 19, 21, accessed online on 5 Aug 2016; $<$ https://www.google.com/url? sa $=$ t $\& r c t=j \& q=\&$ esrc $=$ s \& source $=w e b$ $\& \mathrm{~cd}=1 \& \mathrm{cad}=\mathrm{rja} \& \mathrm{u}$ act $=\quad 8 \& \mathrm{ved}=0$ ahUKEwi62veNgarOA hXE o48K Hdf9AEgQFggi MAA\&url=http\%3A\%2F\%2Fjournals2Fjournals.iium. edu.my $\% 2$ Fintdiscourse $\% 2$ Findex.php $\% 2$ Fislam $\% 2$ Farticle $\% 2$ Fdownload \%2F479\%2F 2F425\&usg=AFQjCNF0zWrxh6OGGp5k8rraEQFrIz9vVw>

17. Rafiu Ibrahim Adebayo "Islamization of knowledge: its inevitability and problems of practicability in Nigeria," pp. $4-17$, p. 5 .

18. The first of the conferences on the Islamisation of knowledge was organised by the Association of Muslim Social Scientists (AMSS). The remaining three were organised by the US-based International Institute for Islamic Thought, (IIIT).

19. This conference took place in 1996, in Cape Town, South Africa.

20. The new classification of knowledge reflected the recognition that knowledge was not monolithic and confined only to religious knowledge.

21. Mohammad Hashim Kamali, The Right to Education, Work and Welfare in Islam, Ilmiah Publishers, 2013, p. 41.

22. Ghulam Nabi Saqeb "Islamization of Education," p. 116. 
23. Rafiu Ibrahim Adebayo "The Influence of the World Conferences on Muslim Education on Islamic Education in Nigeria," University of Ilorin, Nigeria, accessed online on 4 Aug. 2016; <http://unilorin.edu.ng/publications/adebayori/ The\%20Influence\%20of\%20wolrd\%20conference.htm $>$

24. Ghulam Nabi Saqeb "Some Reflections on Islamization of Education Since 1977 Makkah Conference: Accomplishments, Failures and Tasks Ahead," Intellectual Discourse, Vol. 8, No. 1, 2000, pp. 45-68, pp. 52 - 53, accessed online on 11 July 2016; <https:/www.google.com/url?sa=t\&rct=j\&q=\&esrc $=$ s\&source $=$ web\&cd $=7 \&$ cad $=$ rja\&uact $=8 \quad \& v e d=0$ ahUKEwiuwumJ1OrNAh UDs48KHbEHDU4QFghBMAY \&url=http $\% 3 \mathrm{~A} \% 2 \mathrm{~F} \% 2 \mathrm{Fjournals.iium.edu.}$ my $\% 2$ Fintdiscourse $\% 2$ Findex.php $\% 2$ Fislam $\% 2$ Farticle $\% 2$ Fdownload $\% 2$ F 481 \%2F426\&usg=AFQjCNE_gVfDTNyr7hb7sfOV9DtSvirxiQ>

25. Id, p. 53.

26. Loc. Cit.

27. Syed Ali Ashraf, quoted in Mohammad Hashim Kamali, The Right to Education, Work and Welfare in Islam, Ilmiah Publishers, 2013, p. 42.

28. Ghulam Nabi Saqeb "Some Reflections on Islamization of Education Since 1977 Makkah Conference: Accomplishments, Failures and Tasks Ahead," pp. 45-68, p. 53.

29. Loc. Cit.

30. The Conference took place in Lugano, the business headquarters of Yussuf Nada, known as the "foreign minister" of the Muslim Brotherhood. Nada played a central role in organising the Conference, which was attended by about thirty leaders of the Muslim Brotherhood. The attendees included Kurshid Ahmad, Abdul Hamid Abu Sulaiman, and Yusuf al-Qaradawi. See Lorenzo Vidino, The New Muslim Brotherhood in the West, Columbia University Press, p. 34, accessed online on 12 July 2016;

$<$ https://books.google.com.my/books?id=OK_GAgAAQBAJ\&pg=PA34\&lpg $=\mathrm{PA} 34 \& \mathrm{dq}=\% 22 \mathrm{Conference}+\mathrm{on}+$ the + Islamization + of + Knowledge $\% 22+\mathrm{AND}$

+ Qaradawi+AND+Switzerland+AND+Lugano+AND+1977\&source=bl\&ots $=\mathrm{o} 2 \mathrm{WGT} 50$ sza\&sig=5eUgxpMc-AQM5ukoHD_3t9K1QRE\&hl=en\&sa=X\&re dir $\mathrm{esc}=\mathrm{y} \# \mathrm{v}=$ onepage $\& \mathrm{q}=\% 22 \mathrm{Conference} \% 20 \mathrm{on} \% 20$ the $\% 20$ Islamization $\% 20$ of $\%$ 20Knowledge $\% 22 \% 20$ AND $\% 20$ Qaradawi $\% 20$ AND $\% 20$ Switzerland $\% 20$ AND\%20Lugano\%20AND\%201977\&f=false $>$

31. Ibrahim Kalin, Editor "Education," The Oxford Encyclopedia of Philosophy, Science and Technology in Islam, with an Introduction by John L. Esposito, Vol. 1, Oxford University Press, 2014, pp. 191 - 198, p. accessed online on 11 July 2016;

$<$ https://books.google.com.my/books?id=or-6BwAAQBAJ\&pg=PA196 $\& \operatorname{lpg}=$ PA $196 \& d q=$ The + first + International + Conference + on + the + Islamiz ation + of + Knowledge $+1977+\mathrm{in}+$ Switzerland\&source $=$ bl\&ots $=6$ enVK_ds

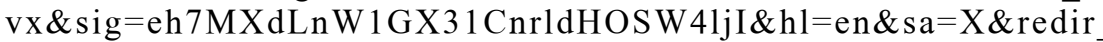
esc $=y \# v=$ onepage $\& q=$ The $\% 20$ first $\% 20$ International $\% 20$ Conference $\% 2 \overline{0}$ on $\% 20$ the $\% 20$ Islamization $\% 20$ of\%20Knowledge\%201977\%20in \%20 Switzerland\&f=true $>$

32. Nasim Ashraf "The Islamization of Pakistan's Educational System: 1979-1989," The Islamization of Pakistan, 1979-2009, The Middle East Institute Washington, 
DC, pp. 25 - 27, accessed online on 11 July 2016; <https:/www.files.ethz.ch/ isn/103356/No_16_Pakistan\%201979-2009.pdf>

33. M. A. Muhibbu-din, (Ed.) Globalization and Terrorism: The Response of Islamic Scholarship, Nigeria Association of Teachers of Arabic And Islamic Studies, 2006, pp. 177 - 178, accessed online on 13 July 2016; <http://unilorin.edu. $\mathrm{ng} /$ publications/adebayori/Adebayo $\% 20 \mathrm{R} \% 20 \mathrm{The} \% 20$ Viability $\% 20$ of $\% 20$ Islamization.pdf $>$

34. Id, p. 178.

35. n.a. Islam: Source and Purpose of Knowledge, Proceedings and Selected Papers of the Second Conference on Islamization of Knowledge 1402 AH / 1982 AC The International Institute of Islamic Thought, USA, 1981, p. viii, accessed online on 12 July 2016; <https://books.google.com.my/books?id=GFhEIF19hr $\mathrm{cC} \&$ printsec $=$ frontcover\&source $=\mathrm{gbs} \_\mathrm{ge}$ _summary_r\&cad $=0 \# \mathrm{v}=$ onepage $\& \mathrm{q} \&$ $\mathrm{f}=$ false $>$

36. Asmady Idris “Malaysia's Relations with Saudi Arabia Under Tun Dr. Mahathir Era, 1981-2003," Seminar on National Resilience, pp. 153 - 154, accessed online on 13 July 2016; <http://repo.uum.edu.my/3171/1/S7.pdf>

37. Isma'il al-Faruqi, quoted in M. A. Muhibbu-din, (Ed.) Globalization and Terrorism: The Response of Islamic Scholarship, Nigeria Association of Teachers of Arabic and Islamic Studies, 2006, p. 186, accessed online on 13 July 2016; < http://unilorin.edu.ng/publications/adebayori/Adebayo\%20R\%20 The $\% 20$ Viability\%20of\%20Islamization.pdf>

38. M. A. Muhibbu-din, (Ed.) Globalization and Terrorism: The Response of Islamic Scholarship, p. 178.

39. Ziauddin Sardar "Beyond the troubled relationship," Nature, 11 July 2007, accessed online on 24 May 2016; <http://www.nature.com/nature/journal/v448/ n7150/full/448131a.html>

40. Loc. Cit.

41. Athar Osama, "Muslim science must join the $21^{\text {st }}$ century," SciDevNet, 3 November 2006, accessed online on 7 May 2016; <http://www.scidev.net/asiapacific/innovation/opinion/muslim-science-must-join-the-21st-century-seaap. html>

42. Loc. Cit.

43. Mohammad Hashim Kamali "The Religious Thrust of Islamic Civilisation," Islam and Civilisational Renewal, Vol. 4, No. 4, October 2013, International Institute for Advanced Islamic Studies, p. 636.

44. Athar Osama, "Islamic countries 'dragging their feet' on science plan," SciDevNet, 11 Sep. 2007, accessed online on 24 May 2016; <http://www.scidev. net/asia-pacific/capacity-building/news/islamic-countries-dragging-their-feeton-science-seaap.html>

45. Zakri Abdul Hamid, Chairman of the Task Force on Science at Universities in the Muslim World, $16^{\text {th }}$ of December 2014, in Kuala Lumpur. Dyna Rochmyaningsih, "Scholars urge science education reforms in Muslim world," SciDevNet, 17 Dec. 2014, accessed online on 24 May 2016; <http:/www.scidev.net/asia-pacific/ education/news/scholars-urge-science-education-reforms-in-muslim-world. html>

46. Ali Riaz, Faithful Education, Rutgers University Press, 2008 pp. 223 - 224, 
accessed online on 31 May 2016; <104.196.101.240/faithful-education-by-aliriaz.pdf>

47. Loc. Cit.

48. Mohammad Hashim Kamali "Reading the signs: the Qur'anic perspective on thinking," Islam and Science, Volume 4, Number 2, Winter 2006, Center for Islam and Science, p. 143.

49. Max Planck, quoted in Mohammad Hashim Kamali, "Islam, rationality and science," Islam and Science, Volume 1, Number 1, June 2003, Center for Islam and Science, pp. 115 - 134, p. 118.

50. In Malaysia, the financial sector alone aimed to employ between 48,000 to 60,000 graduates in 2010 alone, about eight to ten times more than in 2002 (when it hired 6000 employees). M. B. Muda "Islamic Studies in Institutions of Higher Learning in Malaysia: Challenges and Prospects," Islamic Studies in World Institutions of Higher Learning, Abd. Samat Musa, Hazleena Baharun, and Abd. Karim Abdullah (Eds.), Islamic University College of Malaysia, 2004, p. 55.

51. Aaron Segal, Why Does the Muslim World Lag in Science?" The Middle East Quarterly, Middle East Forum, Vol. III, No. 2, June 1996, p. 4, accessed online on 8 June 2016; <http://www.meforum.org/306/why-does-the-muslim-worldlag-in-science>

52. M. Bakri Musa "The Havoc Education Reform Inflicts (Part 4 of 5)," October 2012, accessed online on 29 may 2016; <http://bakrimusa.blogspot.my/2012/10/ the-havoc-education-reform-inflicts.html $>$

53. Other factors that have been blamed for causing the decline in Islamic civilisation include: "the alienation of the Muslim community from its religion ... [the] educational system ... [and] scientific and technical shortcomings ..." Abd al-Hamid al-Ansari "A critique of the Muslim mind," Islam and rationality, Almuslih.org, accessed online on 27 July 2016; <http://www.almuslih.org/index. php?option=com_content $\&$ view $=$ article $\&$ id $=196$ :a-critique-of-the-muslimmind\&catid $=56:$ islam-and-rationality\&Itemid $=245>$

54. Mohammad Hashim Kamali "Reading the signs: the Qur'anic perspective on thinking," p. 158.

55. Ziauddin Sardar "Beyond the troubled relationship."

56. "From the Qur'anic vantage point, the sciences of nature should be key to our cognition of the signs of God in the universe." Mohammad Hashim Kamali "Reading the signs: the Qur'anic perspective on thinking," p. 162.

57. Loc. Cit.

58. AbdulHamid A. AbuSulayman, Crisis in the Muslim Mind, trans. by Yusuf Talal DeLorenzo, The International Institute of Islamic Thought, Herndon, Virginia USA, 1993, p. 17; accessed online on 14 July 2016; <https://www.google. $\mathrm{com} / \mathrm{url}$ ? $\mathrm{sa}=\mathrm{t} \& \mathrm{rct}=\mathrm{j} \& \mathrm{q}=\&$ esrc $=$ s\&source $=$ web $\& \mathrm{~cd}=1 \& \mathrm{cad}=\mathrm{rja} \& u a c t=8 \& \quad$ ve $\mathrm{d}=0$ ahUKEwiJ4sCdwPLNAhVJs48KHSuYBV4QFggeMAA\&url=http $\% 3 \mathrm{~A}$ $\% 2 \mathrm{~F} \% 2 \mathrm{Fphilclubcle.org} \% 2 \mathrm{Fpapers} \% 2 \mathrm{FScharf} \% 2 \mathrm{CW} 20041123$.pdf\&usg= AFQjCNGJyBiW707qFNqQ0QftS1X_pddZfw>

59. Mohammad Hashim Kamali, "Islam, rationality and science," pp. $121-122$.

60. The Right to Education, Work and Welfare in Islam, Ilmiah Publishers, 2013, p. 84. 
61. There are 37 international branch campuses of foreign universities (IBCs) operating in "free zones" in the UAE. The quality of education in these institutions is monitored by home universities. Daniel R. Judd, The Dubai International Conference in Higher Education 2013, Brown Walker Press, 2013, p. 136, accessed online on 6 June 2016; <https://books.google.com.my/books?id $=$ eeWVBAAAQBAJ\&pg=PA246\&lpg=PA246\&dq=Fourth+Dubai+conference + on + education \& source $=$ bl\&ots $=$ qvHSb3jvGX\&sig $=$ EWaBPjKu8HHZFe9JyLz ewHksBaM\&hl=en\&sa $=$ X\&redir_esc $=y \# v=$ onepage\&q $\& \mathrm{f}=$ false $>$

62. Malaysia has twenty public universities, twenty-four polytechnic institutions, thirty-seven public sector community colleges, thirty-three privately operated universities, five branch campuses of foreign universities, and more than five hundred private colleges. Selvaraj Grapragasem, Anbalagan Krishnan, and Azlin Norhaini Mansor "Current Trends in Malaysian Higher Education and the Effect on Education Policy and Practice: An Overview," International Journal of Higher Education, Vol. 3, No. 1; 2014, pp. 85 - 93, p. 86, accessed online on 14 July 2016; <http://files.eric.ed.gov/fulltext/EJ1067468.pdf>

63. As Rifa'ah Tahtawi (1801-1873) was an Egyptian scholar who remarked, "These sciences were once Islamic when we were at the apex of our civilization. Europe took them from us and developed them further. It is now our duty to learn from them just as they learned from our ancestors ..." quoted in Azzam S. Tamimi, Rachid Ghannouchi A Democrat Within Islamism, Religion and Global Politics, Editor, John L. Esposito, Oxford University Press, 2001, p. 111, accessed online on 10 August, 2016; <https://cscsebook.files.wordpress.com/2015/03/rachidghannouchi-a-democrat-within-islamism.pdf> 